\title{
Dog as a Potential Source of Helicobacter pylori in Egypt: Public Health Significance
}

\author{
Rehab Elhelw ${ }^{1}$, Mahmoud Elhariri ${ }^{1}$, Eman Ragab ${ }^{1}$, Mona Kadry $^{2}$ and Dalia Hamza ${ }^{2}$ * \\ ${ }^{I}$ Department of Microbiology, Faculty of Veterinary Medicine, Cairo University, Egypt. \\ ${ }^{2}$ Department of Zoonoses, Faculty of Veterinary Medicine, Cairo University, Egypt. \\ *Corresponding author's Email: daliahamza@cu.edu.eg; (DORCiD: 0000-0001-7579-5432
}

\begin{abstract}
Helicobacter species are a group of Gram-negative, microaerophilic bacteria, which are known to colonize the gastrointestinal and biliary tracts of humans and various animal species. The objective of the present study was to determine the prevalence of Helicobacter pylori in owned dogs and their role in the transmission of $H$. pylori to the dog owners. For this purpose, 60 gastric biopsy samples from dog owners and 80 stool samples from owned dogs were collected and examined for the presence of $H$. pylori 16s $r R N A$ gene by nested PCR. The PCR positive samples from human and dog isolates were further subjected to partial Helicobacter genus-specific 16s rRNA gene sequencing. Phylogenetic analysis based on partial sequence of this gene was performed to determine the relationship between human and dog isolates. H. pylori was detected in $62.5 \%$ and $91.6 \%$ of dog and human samples, respectively. The nucleotide sequence of Helicobacter genus-specific $16 \mathrm{~s} r R N A$ gene of human and dog isolates were similar. In conclusion, this study indicated a high prevalence of $H$. pylori in both dogs and dog owners in Egypt. Zoonotic transmission of $H$. pylori between dogs and humans is probable and represents a public health concern.
\end{abstract}

Keywords: Dogs, Helicobacter pylori, Humans, Phylogenetic analysis, 16s rRNA sequencing

\section{INTRODUCTION}

Helicobacter pylori is a spiral, Gram-negative microaerophilic bacterium that prefers commonly the acidic medium, because of its ability to produce urease (Siqueira et al., 2007). It is considered to be the second predisposing cause of cancer-associated deaths and the fourth cancer-causing factor all over the world (The Globocan Project, 2010). It is reported that above half of the world's people with a higher percentage of adults are affected by $H$. pylori infection, especially in developing countries (Frenck and Clemens, 2003).

Helicobacter species inhabits the gastric and intestinal mucosa of humans, pet animals including dogs and cats, avian species, as well as wild animals such as monkeys (Abdi et al., 2014; Hong et al., 2015). In humans, H. pylori mainly invade the mucosa of the stomach. The majority of Helicobacter infections may develop to asymptomatic gastritis, nevertheless, $10 \%$ of infections may progress to cause gastric or duodenal ulcers, and $1 \%$ may develop into gastric carcinoma (Beswick et al., 2006). It is well known that there is close contact between humans and companion animals, which poses a great risk of transmitting many zoonotic diseases. Most of these infections in humans initiate from animals, including dogs, through direct contact (Meining et al., 1998; Haesebrouck et al., 2009).

In dogs, spiral-shaped bacteria are commonly found in the stomach. They are present in $67-86 \%$ of clinically healthy dogs and 61-100\% of dogs presenting chronic vomiting (Hwang et al., 2002; Recordati et al., 2007). Many studies have reported that the majority of dogs affected with gastric ulcers may act as a reservoir of $H$. pylori. These studies have been reported in many countries such as Belgium (Van den Bulck et al., 2005), Thailand (Pirarat et al., 2003), Italy (Recordati et al., 2007), Iran (Torkan and Shahreza, 2016), and Egypt (Abdel-Raouf et al., 2014). The prevalence of gastric Helicobacter infection in dogs has been reported to be between 61 to 100\% (Eaton et al., 1996; Happonen et al., 1998; Yamasaki et al., 1998; Wiinberg et al., 2005). Also, a relationship has been found between pet ownership or frequent exposure to dogs and infection with different gastric Helicobacter species (Chung et al., 2013).

Therefore, domestic animals, especially dogs, are charged to be a common source of Helicobacter (Abdi et al., 2014; Okubo et al., 2017). The isolation of Helicobacter spp. from saliva, dental plaque, and feces of dogs reinforces the hypothesis of transmission from these animals through oral-oral or fecal-oral routes (Souza et al., 2004). The same condition is observed in humans with $H$. pylori infection, i.e., oral-oral and fecal-oral are considered possible routes of transmission (Brown, 2000). The occurrence of H. pylori in dogs and humans enhances the need for Helicobacter detection and companion animal treatment (Nowroozilarki et al., 2017). Therefore, eradication of Helicobacter 
infections in dogs that have close contact with humans should be considered as one of the methods to control this zoonotic infection.

The aim of this research was to study the prevalence of $H$. pylori infection in owned dogs and dog owners of Egypt and its public health significance.

\section{MATERIALS AND METHODS}

\section{Ethical approval}

This study was conducted according to ethical guidelines approved by the Faculty of Veterinary Medicine, Cairo University, Egypt. The signed consent for the use of samples was obtained from each patient who participated in the study.

\section{Sample collection}

Gastric biopsy samples ( $\mathrm{n}=60)$ of patients with the history of dog ownership were collected from different hospitals in Giza, Egypt. Canine stool samples $(n=80)$ were collected from the hospital of the Faculty of Veterinary Medicine, Cairo University, and other private veterinary clinics in the Giza governorate. Biopsy and stool samples were collected in sterile tubes containing Brain Heart Infusion (BHI) broth (Merck, Germany) and 5\% non-activated fetal calf serum and transferred on ice to the laboratory.

\section{Molecular identification of Helicobacter pylori by nested PCR targeting 16S rRNA gene}

DNA was extracted from stool samples using QIAamp DNA Stool Mini Kit, (Germany) according to the manufacturer's instructions. While for gastric biopsies, DNA was extracted by a modification of the method described by (Marais et al., 1999). The extracted DNA was stored at $-20{ }^{\circ} \mathrm{C}$ until required. The nested PCR assay targeting the $16 S$ rRNA gene of $H$. pylori was performed using primer pairs Hp1, Hp2, and Hp3 (Table 1) (Hamza et al., 2018). The temperature profile was as follows: $30 \mathrm{~s}$ at $95{ }^{\circ} \mathrm{C}, 30 \mathrm{~s}$ at 55 or $60{ }^{\circ} \mathrm{C}$, and $30 \mathrm{~s}$ at $72{ }^{\circ} \mathrm{C}$. For nested PCR, 25 cycles were used for each round of amplification. PCR products were analyzed on $2 \%$ agarose gel electrophoresis stained with ethidium bromide.

\section{Sequencing of Helicobacter genus-specific $16 \mathrm{~S}$ rRNA gene}

To study the relationship between $H$. pylori isolated from human and dog, the extracted DNA from PCR positive samples were amplified for Helicobacter genus-specific 16s rRNA gene using C97 and C05 primers (Table 1) (Elhariri et al., 2017). The temperature profile was as follows: $94{ }^{\circ} \mathrm{C}$ for $1 \mathrm{~min} ; 55^{\circ} \mathrm{C}$ for $2.5 \mathrm{~min}$; $72{ }^{\circ} \mathrm{C}$ for $3 \mathrm{~min}$ ( 35 cycles). The PCR products were purified using a Qiaquick purification kit (Qiagen, Germany) and sequenced using Big Dye Terminator V3.1 sequencing kit (Applied Biosystems, Waltham, MA, USA). The obtained nucleotide sequences from human and dog isolates were submitted to the GenBank under accession numbers MN901212 and MN901172, respectively.

\section{Phylogenetic analysis}

The nucleotide sequences in the current study were compared with those available in GenBank databases using the NCBI-BLAST server. Sequences were downloaded and imported into the BioEdit program version 7.0.1.4 for multiple alignments using the BioEdit Clustal W program. Phylogenetic analysis was performed with the MEGA program version 7 using the neighbor-joining approach.

Table 1. Primers used in this study

\begin{tabular}{lccc}
\hline Target genes & Primers & Sequences (5'-3') & PCR product size (base pair) \\
\hline $\begin{array}{l}\text { Helicobacter } \text { genus-specific } \\
\text { 16s rRNA }\end{array}$ & C97-F & GCT ATG ACG GGT ATC C & 1200 \\
\hline \multirow{2}{*}{ Helicobacter pylori-specific- } & C05-R & ACT TCA CCC CAG TCG CTG & 109 \\
16 s rRNA & HP2-F & CTGGAGAGACTAAGCCCTCC & 109 \\
\hline
\end{tabular}

F: forward, R: reverse

\section{RESULTS}

H.pylori was detected by nested PCR assay targeting the $16 S$ rRNA gene of $H$. pylori in $62.5 \%(50 / 80)$ and $91.6 \%$ $(55 / 60)$ of owned dogs and humans, respectively. The nucleotide sequences of Helicobacter genus-specific $16 \mathrm{~s} r R N A$ from human and dog isolates were located in the same cluster with a bootstrapping value $99 \%$ (Figure 1), indicating that they are highly related to each other. The similarity was found between H. pylori isolated from both dogs and human cases. 


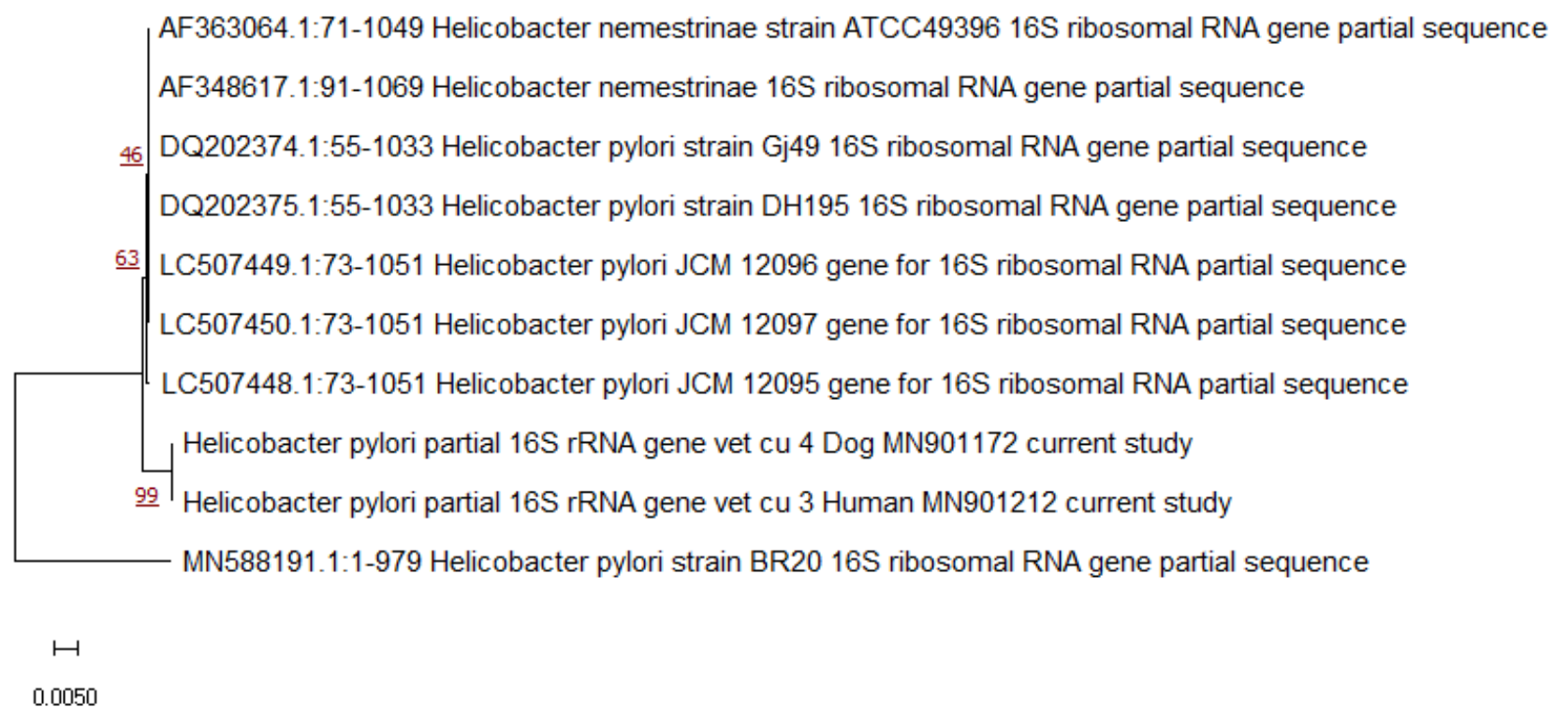

Figure 1. Neighbor-joining tree based on the nucleotide sequences of the partial coding regions of 16s $r R N A$ gene of $H$. pylori from human and dog isolates. The Evolutionary analysis was performed with MEGA version 7.

\section{DISCUSSION}

Previous findings revealed that dogs may play an important role in the transmission of $\mathrm{H}$. pylori to humans (Recordati et al., 2007; Abdel-Raouf et al., 2014). Many researches indicated that the prevalence of $H$. pylori is high in dogs and may reach 100\% (Wiinberg et al., 2005; Okubo et al., 2017). In the current study, 62.5\% of dog stool samples were positive for $\mathrm{H}$. pylori by PCR, which is similar to the findings of Hong et al. (2015) who detected Helicobacter spp. DNA in feces of laboratory dogs. In a study carried out by Zou et al. (2019) in China, it was found that dogs were the main homereared animals and the positive rate of $\mathrm{H}$. pylori infection was higher in people who breed dogs. Epidemiological data revealed that ownership of dogs is a risk factor for $\mathrm{H}$. pylori infection in children in the rural areas and it was concluded that dogs could be a potential source of bacteria (Dore et al., 2002).

The investigations revealed that dogs, especially those suffering from gastric ulcer, may be the reservoir of $H$. pylori and/or might be the original host of this bacterium (Torkan and Shahreza, 2016). A study conducted by Hamza et al. (2018) showed that higher rates of $\mathrm{H}$. pylori detection in gastric biopsies of dogs using PCR (76.6\%) and cultivation $(89.1 \%)$.

The prevalence rate of $H$. pylori infection was found to be lower in developed countries than in developing countries. The rate of $\mathrm{H}$. pylori infection is generally lower than $30 \%$ in developed countries, while it may be as high as 50-70\% in developing countries (Pounder and Ng, 1995). Some studies have pointed out that the poor economic status and a lower degree of culture may induce higher $\mathrm{H}$. pylori infection rates (Hu, 2008). Poor hygiene conditions and close contact with stray animals could be risk factors that increase the prevalence of Helicobacter infections (Bolandi et al. 2017). Moreover, the research conducted by Bolandi et al. (2017) on household dogs raised under hygienic conditions and fed with cooked food revealed a low prevalence $(8.66 \%)$ of $\mathrm{H}$. pylori infection. Although there is a significant presence of Helicobacter in dogs, it is not possible to relate it with gastric alterations in these animals (Rossi et al., 1999; Moutinho et al., 2007; Takemura et al., 2007). H. pylori infect about $50 \%$ of the world's human population associated with gastric and extra gastric diseases (Bravo et al., 2018). H. pylori is responsible for peptic ulcer, gastritis, lymphoma, duodenal ulcer, and gastric cancer (Atapoor et al., 2014; Ghorbani et al., 2016).

In this study, H. pylori was detected in $91.6 \%$ of dog owners. This differs from El-Shenawy et al. (2017) who reported that the prevalence rate of $\mathrm{H}$. pylori in Egyptian patients was 53.1\%, but similar to the finding of Abu-Zekry et al. (2013) that $H$. pylori infection was detected by culture method in $70 \%$ of gastric biopsy specimens. This difference may be due to a variety of contributing factors, including socioeconomic status, living conditions, and location of each population even in the same country.

In Egypt, serological detection of H. pylori was done by Elhariri et al. (2017) in dogs and humans and found that $37.2 \%$ and $44.4 \%$ were positive, respectively. This indicates the zoonotic importance and the possibility of transmission of disease between dogs and their owners. It is clear that some animals, including cats, dogs, and sheep may be infected by H. pylori, but their roles in the transmission to humans are not proved (Mladenova-Hristova et al., 2017). 
H. pylori infection in Human probably resulted from a host jump from a different animal (Dewhirst et al., 2005). Host jump is not impossible, in light of the fact that the stomachs of different animals are contaminated with various Helicobacter species, whose phylogeny is incongruent with that of their hosts. In fact, the closest known relative of $H$. pylori is $H$. acinonychis, which invade large cats and appears to have emerged by a host jump from humans (Eppinger et al., 2006).

The theory of host jump of $H$. pylori was reinforced by making the phylogenetic relationship between human and dog samples which showing $100 \%$ homology between each other and this reflects the possibility of the transmission of this bacteria between dogs and their owners. This finding has been documented previously from all around the world, including Egypt, where (Abdel-Raouf et al., 2014) suggested that Helicobacter colonizes the stomachs and intestines of humans and several animal species such as cats, dogs and might have jumped quite recently from animal hosts to people.

\section{CONCLUSION}

The high prevalence of $H$. pylori in dog owners proved the role of the owned dogs in the transmission of this pathogen. The evidence of $H$. pylori transmission from dogs to humans enhances the need for Helicobacter detection and treatment in pet animals.

\section{DECLARATION}

\section{Authors' contributions}

Rehab Elhelw, Mahmoud Elhariri, Eman Ragab, Mona Kadry, and Dalia Hamza contributed to the collection of samples, isolation of strains, performing the molecular detection of target genes, analysis and interpretation of the data as well as writing the manuscript. All authors read and approved the final manuscript.

\section{Acknowledgments}

The authors declare that they did not have any funding source or grant to support their research work.

\section{Competing interests}

The authors declare that they have no competing interests.

\section{REFERENCES}

Abdel-Raouf M, Abdel-Gleel Y and Enab A (2014). Study on the role of pet animals for Helicobacter pylori transmission. Journal of American Science, 10(8s): 20-28. Available at: http://www.jofamericanscience.org/journals/am-sci/am1008s/002_27437am1008s14_20_28.pdf

Abdi FS, Jamshidi S, Moosakhani F and Sasani F (2014). Detection of Helicobacter spp. DNA in the colonic biopsies of stray dogs: molecular and histopathological investigations. Diagnostic Pathology, 9 (1): 50. DOI: http://www.doi.org/10.1186/1746-1596-9-50.

Abu-Zekry MA, Hashem ME, Ali AA and Mohamed IS (2013). Frequency of Helicobacter pylori infection among Egyptian children presenting with gastrointestinal manifestations. The Journal of The Egyptian Public Health Association, 88(2): 74-78. DOI: http://www.doi.org/10.1097/01.EPX.0000430958.09388.0e.

Atapoor S, Dehkordi FS and Rahimi E (2014). Detection of Helicobacter pylori in various types of vegetables and salads. Jundishapur Journal of Microbiology, 7(5): e10013. DOI: http://www.doi.org/10.5812/jjm.10013.

Beswick EJ, Suarez G and Reyes VE (2006). H. pylori and host interactions that influence pathogenesis. World Journal of Gastroenterology, 12(35): 5599. DOI: http://www.doi.org/10.3748/wjg.v12.i35.5599.

Bolandi A, Torkan S and Alavi I (2017). Genotyping pattern of the vacuolating cytotoxin A and cytotoxin associated gene A of the Helicobacter pylori strains detected in fecal samples of household dogs. Microbiology Research, 8(2): 47-50. DOI: https://www.doi.org/10.4081/mr.2017.7289.

Bravo D, Hoare A, Soto C, Valenzuela MA and Quest (2018). Helicobacter pylori in human health and disease: Mechanisms for local gastric and systemic effects. World Journal of Gastroenterology, 24(28): 3071. DOI: http://www.doi.org/10.3748/wjg.v24.i28.3071.

Brown LM (2000). Helicobacter pylori: epidemiology and routes of transmission. Epidemiologic Reviews, $22(2)$ : $283-297$. DOI: http://www.doi.org/10.1093/oxfordjournals.epirev.a018040.

Chung TH, Kim HD, Lee YS and Hwang CY (2013). Determination of the prevalence of Helicobacter heilmannii-like organisms type 2 (HHLO-2) infection in humans and dogs using non-invasive genus/species-specific PCR in Korea. Journal of Veterinary Medical Science, 76 (1): $73-79$. DOI: https://www.doi.org/10.1292/jvms.13-0223

Dewhirst FE, Shen Z, Scimeca MS, Stokes LN, Boumenna T, Chen T, Paster BJ and Fox JG (2005). Discordant 16S and 23S rRNA gene phylogenies for the genus Helicobacter: implications for phylogenetic inference and systematics. Journal of Bacteriology, 187(17): 6106-6118. DOI: https://www.doi.org/10.1128/JB.187.17.6106-6118.2005.

Dore MP, Malaty HM, Graham DY, Fanciulli G, Delitala G and Realdi G (2002). Risk factors associated with Helicobacter pylori infection among children in a defined geographic area. Clinical Infectious Diseases, 35(3): 240-245. DOI: https://www.doi.org/10.1086/341415.

Eaton KA, Dewhirst FE, Paster BJ, Tzellas N, Coleman BE, Paola J and Sherding R (1996). Prevalence and varieties of Helicobacter species in dogs from random sources and pet dogs: animal and public health implications. Journal of Clinical Microbiology, 34(12): 3165-3170. Available at: https://jcm.asm.org/content/34/12/3165.

Elhariri M, Elhelw R, Hamza D and El-Mahallawy HS (2017). Serologic evidence and risk factors for Helicobacter pylori infection in animals and humans. The Journal of Infection in Developing Countries, 11(05): 414-419. DOI: https://www.doi.org/10.3855/jidc.9339.

El-Shenawy A, Diab M, Shemis M, El-Ghannam M, Salem D, Abdelnasser M, Shahin M, Abdel-Hady M, El-Sherbini E and Saber M (2017). Detection of Helicobacter pylori vacA, cagA and iceA1 virulence genes associated with gastric diseases in Egyptian patients. Egyptian Journal of Medical Human Genetics, 18(4): 365-371. DOI:https://www.doi.org/10.1016/j.ejmhg.2017.04.003. 
Eppinger M, Baar C, Linz B, Raddatz G, Lanz C, Keller H, Morelli G, Gressmann H, Achtman M and Schuster SC (2006). Who ate whom? Adaptive Helicobacter genomic changes that accompanied a host jump from early humans to large felines. PLoS Genetics, 2(7): e120. DOI: https://www.doi.org/10.1371/journal.pgen.0020120

Frenck Jr RW and Clemens J (2003). Helicobacter in the developing world. Microbes and Infection, 5(8): 705-713. DOI: https://www.doi.org/10.1016/S1286-4579(03)00112-6.

Ghorbani F, Gheisari E and Dehkordi FS (2016). Genotyping of vacA alleles of Helicobacter pylori strains recovered from some Iranian food items. Tropical Journal of Pharmaceutical Research, 15(8): 1631-1636. DOI: https://www.doi.org/10.4314/tjpr.v15i8.5.

Haesebrouck F, Pasmans F, Flahou B, Chiers K, Baele M, Meyns T, Decostere A and Ducatelle R (2009). Gastric helicobacters in domestic animals and nonhuman primates and their significance for human health. Clinical Microbiology Reviews, 22(2): 202-223. DOI https://www.doi.org/10.1128/CMR.00041-08.

Hamza D, Elhelw R, Elhariri M and Ragab E (2018). Genotyping and antimicrobial resistance patterns of Helicobacter pylori in human and dogs associated with A2142G and A2143G point mutations in clarithromycin resistance. Microbial Pathogenesis, 123: 330-338. DOI: https://www.doi.org/10.1016/j.micpath.2018.07.016.

Happonen I, Linden J, Saari S, Karjalainen M, Hänninen ML, Jalava K and Westermarck E (1998). Detection and effects of helicobacters in healthy dogs and dogs with signs of gastritis. Journal of the American Veterinary Medical Association, 213(12): 1767-1774. Available at: https://pubmed.ncbi.nlm.nih.gov/9861972.

Hong S, Chung Y, Kang WG, Choi YS and Kim O (2015). Comparison of three diagnostic assays for the identification of Helicobacter spp. in laboratory dogs. Laboratory Animal Research, 31(2): 86-92. DOI: https://www.doi.org/10.5625/lar.2015.31.2.86.

Hu FL (2008). Helicobacter pylori infection is a research topic involving multiple disciplines. Zhonghua Yi Xue Za Zhi, 88(22): 1513. Available at: https://pubmed.ncbi.nlm.nih.gov/18956628/.

Hwang CY, Han HR and Youn HY (2002). Prevalence and clinical characterization of gastric Helicobacter species infection of dogs and cats in Korea. Journal of Veterinary Science, 3(2): 123-134. DOI: https://www.doi.org/10.4142/jvs.2002.3.2.123.

Marais A, Monteiro L, Occhialini A, Pina M, Lamouliatte H and Megraud F (1999). Direct detection of Helicobacter pylori resistance to macrolides by a polymerase chain reaction/DNA enzyme immunoassay in gastric biopsy specimens. Gut, 44(4): 463-467. DOI: https://www.doi.org/10.1136/gut.44.4.463.

Meining A, Kroher G and Stolte M (1998). Animal reservoirs in the transmission of Helicobacter heilmannii: results of a questionnaire-based study. Scandinavian Journal of Gastroenterology, 33(8): 795-798. DOI: https://www.doi.org/10.1080/00365529850171422.

Mladenova-Hristova I, Grekova O and Patel A (2017). Zoonotic potential of Helicobacter spp. Journal of Microbiology, Immunology and Infection, 50(3): 265-269. DOI: https://www.doi.org/10.1016/j.jmii.2016.11.003.

Moutinho FQ, Thomassian A Watanabe MJ, Suzano SMC and Sequeira JL (2007). Prevalência de helicobactérias e alterações na mucosa gástrica de cães saudáveis. Arquivo Brasileiro de Medicina Veterinária e Zootecnia, 59(4): 1080-1083. DOI: https://www.doi.org/10.1590/S010209352007000400040 .

Nowroozilarki N, Jamshidi S, Salehi TZ and Kolahian S (2017). Identification of Helicobacter and Wolinella spp. In oral cavity of toy breed dogs with periodontal disease. Topics in Companion Animal Medicine, 32(3): 96-99. DOI: https://www.doi.org/10.1053/j.tcam.2017.07.004.

Okubo BM, Ricci-Azevedo R, Zobiole NN, Buccini DF and Moreno SE (2017). Prevalence of Helicobacter spp. in dogs from campo grande-ms. Ciência Animal Brasileira, 18(1): 1-10. DOI: https://www.doi.org/10.1590/1089-6891v18e-17286

Pirarat N, Makbunsri T, Sukkamon S, Amornchailertrat S, Rungsipipat A and Sunyasootcharee B (2003). The relationship between pathological gastric changes and Helicobacter spp. in dogs. The Thai Journal of Veterinary Medicine, 33(3): 73-80. Available at: https://he01.tcithaijo.org/index.php/tjvm/article/view/37660.

Pounder RE and Ng D (1995). The prevalence of Helicobacter pylori infection in different countries. Alimentary Pharmacology and Therapeutics, 9(Suppl 2): 33-39. DOI: https://www.doi.org/10.1111/j.1365-2036.1995.tb00348.x.

Recordati C, Gualdi V, Tosi S, Facchini RV, Pengo G, Luini M, Simpson KW and Scanziani E (2007). Detection of Helicobacter spp. DNA in the ora cavity of dogs. Veterinary Microbiology, 119(2-4): 346-351. DOI: https://www.doi.org/10.1016/j.vetmic.2006.08.029.

Rossi G, Rossi M, Vitali CG, Fortuna D, Burroni D, Pancotto L, Capecchi S, Sozzi S, Renzoni G, Braca G and Del Giudice G. (1999). A conventional beagle dog model for acute and chronic infection with Helicobacter pylori. Infection and Immunity, 67(6): 3112-3120. DOI: https://www.doi.org/10.1128/IAI.67.6.3112-3120.1999.

Siqueira JS, Lima PS, Barreto AS and Quintans-Júnior LJ (2007). Aspectos Gerais nas Infecções por Helicobacter pylori Revisão. RBAC, 39 (1): 9-13. Available at https://www.researchgate.net/publication/280002792_Aspectos_Gerais_nas_Infeccoes_por_Helicobacter_pylori_Revisao.

Souza MLD, Kobayasi S. Rodrigues MAM, Saad-Hossne R and Naresse LE (2004). Prevalência de Helicobacter em cães oriundos do biotério central da Universidade Estadual de São Paulo (UNESP)-Botucatu. Acta Cirurgica Brasileira, 19(5): 565-570. DOI: https://www.doi.org/10.1590/S010286502004000500017.

Takemura LS, Amude AM, Camargo PL and Bracarense APFRL (2007). Detecção e efeitos de Helicobacter spp. em cães sadios e com sinais de gastrite. Acta Scientiae Veterinariae, 35(s2): 480-481. Available at: http://docplayer.com.br/17857152-Deteccao-e-efeitos-de-helicobacter-sppem-caes-sadios-e-com-sinais-de-gastrite.html

The Globocan Project (2010). International Agency for Research on Cancer, The Globocan Project (online). Available at: http://globocan.iarc.fr/.

Torkan S and Shahreza MHS (2016). VacA, CagA, IceA and OipA genotype status of Helicobacter pylori isolated from biopsy samples from Iranian dogs. Tropical Journal of Pharmaceutical Research, 15(2): 377-384. DOI: http://www.doi.org/10.4314/tjpr.v15i2.22.

Van den Bulck K, Decostere A, Baele M, Driessen A, Debongnie JC, Burette A, Stolte M, Ducatelle R and Haesebrouck F (2005). Identification of non-Helicobacter pylori spiral organisms in gastric samples from humans, dogs, and cats. Journal of Clinical Microbiology, 43(5): 2256-2260. DOI: http://www.doi.org/10.1128/JCM.43.5.2256-2260.2005.

Wiinberg B, Spohr A, Dietz HH, Egelund T, Greiter-Wilke A, McDonough SP, Olsen J, Priestnall S, Chang YF and Simpson KW (2005). Quantitative analysis of inflammatory and immune responses in dogs with gastritis and their relationship to Helicobacter spp. infection. Journal of Veterinary Internal Medicine, 19(1): 4-14. DOI: http://www.doi.org/10.1892/0891-6640(2005)19<4:qaoiai>2.0.co;2.

Yamasaki K, Suematsu H and Takahashi T (1998). Comparison of gastric lesions in dogs and cats with and without gastric spiral organisms. Journal of the American Veterinary Medical Association, 212(4): 529. Available at: https://pubmed.ncbi.nlm.nih.gov/9491160/.

Zou J, Xiao YQ, Cheng YF, Ren XY, Li SW and Gang D (2019). Investigation of Helicobacter pylori Infection and Its Related Factors in the Tianjin Binhai Area, China. Jundishapur Journal of Microbiology, 12(9): 1-10. DOI: http://www.doi.org/10.5812/jjm.94845. 